\title{
Analysis of U.S. Economic Under the Covid-19 Epidemic
}

\author{
Cong Lei (Dexter)
}

School: Mesa Grande Academy, 975 Fremont St, Calimesa, CA 92320, USA
*Corresponding author. Email: dexter.lei@mgak-12.org

\begin{abstract}
The Covid-19 has affected millions of people and the U.S. economy. In this article, the author demonstrated how Covid-19 affected people's mental health, caused lack of open restaurants, unemployment, and fewer international students coming to the U.S. It also decreased the workload trades and average growth rate of the U.S. This study further explored the impact of the epidemic on the United States by analyzing the changes in American people's daily life, education, and trade etc. The author found that these all aspects show the covid-19 had affected people's life and the U.S. economy drastically. These problems caused by Covid-19 cannot simply rely on the government or the country. People need to work together to solve economic related problems.
\end{abstract}

Keywords: Covid-19. unemployment, mental health, GDP, economy, trade, and food.

\section{INTRODUCTION}

Since January 2020, the coronavirus has started affecting the world globally, the United States was one of the countries that had been affected the most. The Coronavirus affected health, at the same time, it affected the U.S. economy drastically. During 2020, there were 33.5 million cases and including deaths with $601 \mathrm{~K}$. A huge amount of people are affected by the coronavirus. They lost their family members and their opportunity to work in the workplace. Moreover, international trade and flights were limited due to the U.S. policy which would lower the economic growth in the U.S. There are tons of problems in the United States such as unemployment, international trades, online students, stores being shut down, and mental health. This article will analyze the coronavirus lowered the U.S. economy and lowered the GDP. The author will discuss how the virus affects the economic development of the US economy and the impact of the covid-19 epidemic on people's work and life.

\section{THE IMPACT OF COVID-19 ON AMERICAN SOCIETY}

\subsection{The impact of the epidemic on people's mental health}

The coronavirus, it affected American citizens' mental health. "The COVID-19 pandemic is likely to have profound mental health impacts that pervade racial, ethnic, and class lines in the United States.'[7] As instances of the corona virus disease (COVID-19) maintain to rise, mental persistence is a venture many human beings will face. For mental health, heightened stress responses to the pandemic, is probably to happen in 3 approaches: First, development a brand new episode of an ailment in people with a predisposition to a first-rate psychiatric ailment or an acute exacerbation in people who have already got this type of ailment; Second, development of a trauma or stressor associated ailment, which includes acute stress disorder, Post Traumatic Stress Disorder (PTSD), or adjustment disorders; and third, development of a symptomatic strain reaction that doesn't meet the diagnostic standards of a psychiatric ailment. Alcohol use, post-traumatic stress disorder, anxiety, anger, fear of contagion, perceived risk, uncertainty and mistrust are many onsite and long-term results. Therefore, it will be important for people in need of mental health care and determining the precise psychiatric products and 
remedies needed [6]. In the last week of March 2020, there had been over three million unemployment claims withinside the U.S. In addition to the fear and uncertainty surrounding the management of the spread of disease; unemployment; potential risk to assembly physiological needs of self and loved ones; and the several different bio-psychosocial stressors are all probably to pose a risk to mental well-being. This can happen as acute exacerbations of recognized problems in strong patients, new onset of mental disorders in prone patients, stressor-associated problems, and a number of different psychiatric symptoms [6]. Coronavirus has affected peoples' mental health deeply and it has caused many problems. Many people tend to be depressed, workers could not work as well as before, lowering the company's' productivity. Unemployed people would then need to rely on family members for support which may cause many other problems. Without hardworking workers, it would lower the U.S. economy's productivity and hence total output as a whole.

\subsection{The impact of the epidemic on people's living conditions}

The coronavirus affected people's living conditions. People have to wear masks everywhere they go and be aware of themselves not to be around people. This reduces the communication between people and makes people more isolated. Stores were closed and it limited people's ability to buy daily necessities and foods. Millions of people died from the coronavirus. This destroys their family and their ability to live.
Across the United States, officials are implementing a series of restrictions on social distancing. Orders vary by state, county, and even city. With the surge in cases across the country, restrictions in many areas are being strengthened. During the peak restriction period in late March and early April, more than 310 million Americans accepted instructions ranging from "shelter in place" to "stay at home." Health officials warned that premature relaxation of restrictions could lead to new outbreaks, but many states are still moving forward. [2] This limited American citizen's ability to go outside to work and mobility to offer work. This lowered the U.S. economy and affected the U.S. in the future.

During the quarantine, people were going crazy in the grocery store, there was not even enough toilet paper in the stores. People have to buy stuff beforehand or they have no toilet paper to use. Food was a huge problem during this time, without food, people could not do anything. Food supply chain is considered one of the most important sectors of the economy. It has been seen that COVID-19 has an impact on the entire process from the scene to the consumer. [4] Not only was there weren't enough food for people, but also not enough restaurants for people. During quarantine, tons of restaurants were closed due to the government's policy. Nearly 16,000 restaurants have closed permanently and There have been 26,160 total restaurant closures due to the pandemic. Restaurants lose more income and jobs than any other industry. A survey from the National Restaurant Association in June showed food service lost nearly $\$ 120$ billion in sales during just the first three months of the pandemic. [5]

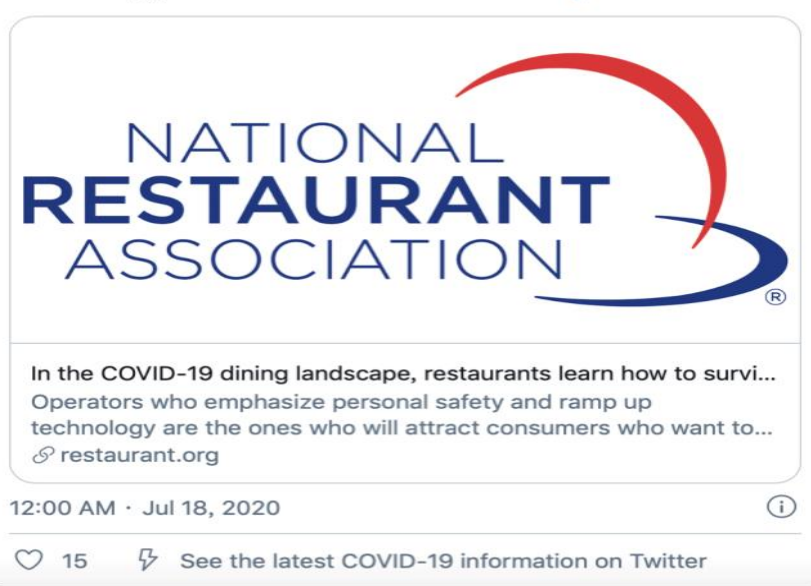

Figure 1 Post from National Restaurant Association on Twitter, 2020. 


\section{ANALYSIS OF ECONOMIC PROBLEMS UNDER THE EPIDEMIC}

\subsection{Increase in unemployment rate}

The most important problem is unemployment. Because there were tons of restaurants closed and permanently closed, there must have been a huge amount of workers who lost their jobs due to the pandemic.

During the quarantine, Employees had been paid less because their companies were not earning the same amount of money as they earned before the quarantine. So the only way to keep the company alive is to reduce the salary of workers. This caused many people to have enough money to buy their rents and bills. Many workers have been working from home during their company's policy. This lowers the trust between the boss and employees which lowers economic growth. Most companies were losing money during the quarantine, for example, most restaurants, barber shops, gyms, and grocery stores were closed. The workers that work for those places tended to lose their jobs because their stores were closed.

On October 7, 2020, There were around 7.7 million people lost their jobs during the quarantine. "A new Pew Research Center survey finds that, overall, one-infour adults have had trouble paying their bills since the coronavirus outbreak started, a third have dipped into savings or retirement accounts to make ends meet, and about one-in-six have borrowed money from friends or family or gotten food from a food bank." [1]. Unemployment is even more serious to other population groups. Overall, around $25 \%$ of American adults were fired or unemployed due to the coronavirus outbreak. These all aspects showed the coronavirus affected workers drastically, it affected their family and their financial ability to pay the bills. This would lower the GDP and the U.S. economy.

\subsection{Education issues}

Students are also affected by it a lot. Students had been doing online classes and this included huge numbers of international students in the U.S. Because of this, many international students decided to go back to their own country to study the online classes. Due to the U.S. policy, all those students that went back couldn't come back easily. This eventually caused many students to end up going back to their own county's school instead of going to U.S. schools and colleges. Because it was hard for those students to come to America. There were way fewer international students coming to the U.S. to study compared to before. International students always pay way more tuition than local American students, without them, it would be tougher for those schools and colleges. This lowered the U.S. economy and affected the future of the U.S.

During covid-19, some schools and colleges reopened after quarantine but they still needed social distancing. Schools not only did not manage to gain extra revenue but also had to spend extra on Covid-19 related products such as face masks, hand-sanitizer, temperature scanners, and take Covid-test kits. If people each school as a firm, then after a significant cost increase, output per unit has to decrease, assuming revenue unchanged. This lowered the U.S. economy and lowered the GDP of the United States.

\subsection{Decrease in world trade}

The coronavirus would cause world trade to decrease. The epidemic was having a huge impact on global economic development. "It is estimated that by now the virus could exceed global economic growth by more than $2.0 \%$ per month if the current situation persists. Global trade may also fall from 13 to $32 \%$ depending on the depth and extent of the global economic slowdown." [3] This research analyses the impact of COVID-19 on the economic growth and stock market as well. This showed the U.S. would have less world trade in the future, without that many trades with other countries, the U.S. economy would be going down gradually.

According to the World Bank data, the average economic growth rate of the world's top 10 economic countries over the last 5 years has been, United States: 2.3\%, China: $2.725 \%$, Japan: $0.925 \%$, Germany: $1.7 \%$, United Kingdom: $1.625 \%$, France: $1.6 \%$, India: $6.4 \%$, Italy: $1.025 \%$, Brazil: $0.1 \%$, Canada: $1.95 \%$. The detailed statistical data over the last 5 years of real GDP.

Table 1 A Statistical Analysis of Impact of COVID19 on the Global Economy and Stock Index Returns, 2021

\begin{tabular}{|c|c|c|c|c|c|}
\hline Country & 2016 & 2017 & 2018 & 2019 & 2020 \\
\hline United States & 1.6 & 2.4 & 2.9 & 2.3 & -5.9 \\
\hline China & 2.2 & 3.3 & 2.7 & 2.7 & -4 \\
\hline Japan & 0.5 & 2.2 & 0.3 & 0.7 & -5.2 \\
\hline Germany & 2.2 & 2.5 & 1.5 & 0.6 & -7 \\
\hline United Kingdom & 1.9 & 1.9 & 1.3 & 1.4 & -6.5 \\
\hline France & 1.1 & 2.3 & 1.7 & 1.3 & -7.2 \\
\hline India & 8.3 & 7 & 6.1 & 4.2 & 1.9 \\
\hline Italy & 1.3 & 1.7 & 0.8 & 0.3 & -9.1 \\
\hline Brazil & -3.3 & 1.3 & 1.3 & 1.1 & -5.3 \\
\hline Canada & 1 & 3.2 & 2 & 1.6 & -6.2 \\
\hline
\end{tabular}


From this table, we can clearly see that in 2020, most countries' average economic growth rate will decrease to a negative percentage. This showed the Covid-19 has impacted the whole world drastically. From 2019 - 2020, The average economic growth rate of the United States from $2.3 \%$ decreased to $-5.9 \%$. This showed the Covid-19 lower average economic growth and lower the GDP of the United States.

\section{DISCUSSION}

Coronavirus had caused many problems, so the government decided to send relief payments to the American citizens. According to the American Rescue Plan Act of 2021, a \$1.9 trillion economic stimulus bill was passed by the 117th Congress of the United States and signed into law by President Joe Biden on March 11, 2021. It aims to accelerate the United States from the COVID-19 pandemic and continued recession. This act helped Americans with their money. Because if they have that money, they would probably not work as hard as they did before.The enthusiasm of American employees will decline. Without as many hardworking workers, it would lower the U.S. economy.

The United States Consumer Price Index (CPI) reached 5\% in May, and its year-on-year growth rate reached $5.4 \%$ in June. It is important to know that CPI over $3 \%$ is inflation, and CPI over $5 \%$ is relatively serious inflation. However, according to people living in the United States, in June, second-hand cars in the United States rose by $10.5 \%$, and house prices rose by $12.7 \%$ year-on-year. A pound of beef was $\$ 10$ a year ago and now costs $\$ 17$. These data show how serious the inflation in the United States is and it would lower the GDP of the United States and lower the U.S. economy. [8]

\section{CONCLUSION}

In conclusion, coronavirus has affected the U.S. economy in many different ways.

First, it affected people's mental health which depressed many workers. It would lower the U.S. economy's productivity and hence total output as a whole. Second, "the stay at home policy " limited American citizen's ability to go outside to work and mobility to offer work. This lowered the U.S. economy and affected the U.S. in the future. Third, closed restaurants made the U.S. lose tons of money and unemployment affects people's families and their financial ability to pay the bills. This would lower the GDP and the U.S. economy. Fourth, education issues during Covid-19 lower the U.S. economy and lower the GDP of the United States. Sixth, the Covid-19 decreased world trade and lowered the average economic growth rate of the United States. Lastly, the relief payment might cause the enthusiasm of American employees to decline. The United States Consumer Price Index (CPI) reached 5\% in May, and its year-onyear growth rate reached $5.4 \%$ in June. These data show how serious the inflation in the United States is and it would lower the GDP of the United States and lower the U.S. economy. This article only studied how Covid-19 affected people and the economy in the United States. All countries over the would get an impact from the Covid-19, In the next field could compare it with the United States and conduct investigations. People could use economic models and questionnaire surveys to see the difference between the U.S. and other countries.

\section{ACKNOWLEDGMENT}

Firstly, I would like to show my deepest gratitude to my teachers and professors in my university, who have provided me with valuable guidance in every stage of the writing of this thesis. Further, I would like to thank all my friends and parents for their encouragement and support. Without all their enlightening instruction and impressive kindness, I could not have completed my thesis.

\section{REFERENCES}

[1] KIM PARKER, RACHEL MINKIN AND JESSE BENNETT , 2020 , Economic Fallout From COVID-19 Continues To Hit Lower-Income Americans the Hardest, Retrieved August 6th, 2021 , https://www.pewresearch.org/socialtrends/2020/09/24/economic-fallout-from-covid19-continues-to-hit-lower-income-americans-thehardest/

[2] "COVID-19 Restrictions Map of COVID-19 Case Trends, Restrictions and Mobility." USA Today, Gannett Satellite Information Network, 6 Aug. 2021, www.usatoday.com/storytelling/coronavirusreopening-america-map/.

[3] Verma, P., Dumka, A., Bhardwaj, A. et al. A Statistical Analysis of Impact of COVID19 on the Global Economy and Stock Index Returns. SN COMPUT. SCI. 2, $27 \quad$ (2021). https://doi.org/10.1007/s42979-020-00410-w

[4] Aday, Serpil, and Mehmet Seckin Aday. "Impact of Covid-19 on the Food Supply Chain." OUP Academic, Oxford University Press, 24 Aug. 2020, academic.oup.com/fqs/article/4/4/167/5896496.

[5] "Nearly 16,000 Restaurants Have Closed Permanently Due to the Pandemic, Yelp Data Shows." ABC News, ABC News Network, abcnews.go.com/Business/16000-restaurantsclosed-permanently-due-pandemic-yelpdata/story?id=71943970. 
[6] Esterwood, E., Saeed, S.A. Past Epidemics, Natural Disasters, COVID19, and Mental Health: Learning from History as we Deal with the Present and Prepare for the Future.Psychiatr Q 91, 1121-1133 (2020). https://doi.org/10.1007/s11126-020-098084

[7] Purtle, J. COVID-19 and mental health equity in the United States. Soc Psychiatry Psychiatr Epidemiol 55, 969-971 (2020). https://doi.org/10.1007/s00127-020-01896-8

[8] Jeff, Cox. "Consumer Prices Jump 5\% in May, Fastest Pace since the Summer of 2008." CNBC, CNBC, 10 June 2021, www.cnbc.com/2021/06/10/cpi-may-2021.html. 